\title{
Stabilization of nickel in a contaminated calcareous soil amended with low-cost amendments
}

\author{
M. Saffari ${ }^{1,2^{*}}$, N. Karimian ${ }^{1}$, A. Ronaghi ${ }^{1}$, J. Yasrebi $^{1}$, R. Ghasemi-Fasaei ${ }^{1}$ \\ ${ }^{I}$ Department of Soil Science, College of Agriculture, Shiraz University, Shiraz, Iran ${ }^{2}$ Institute of Science and \\ High Technology and Environmental Sciences, Graduate University of Advanced Technology, Kerman, Iran. \\ *Corresponding author: MahboubSaffari Mahboobsaffari@gmail.com
}

\begin{abstract}
A laboratory study was planned to delineate the benefits of some low-cost soil amendments on Nickel (Ni) stabilization in a Ni-spiked soil. Six different kinds of amendments were evaluated by desorption kinetic test and sequential extraction procedure to determine their ability to reduce mobility of $\mathrm{Ni}$ in a $\mathrm{Ni}$-spiked soil. The $\mathrm{Ni}$-spiked soil was separately incubated with coal fly ash (CFA), rice husk biochars prepared at $300^{\circ} \mathrm{C}(\mathrm{B} 300)$ and $600^{\circ} \mathrm{C}(\mathrm{B} 600)$, municipal solid waste compost (MSWC), zero valent iron $\left(\mathrm{Fe}^{0}\right)$ and zero valent manganese $\left(\mathrm{Mn}^{0}\right)$ at 2 and $5 \%(\mathrm{~W} / \mathrm{W})$ for 45 and 90 days at $25^{\circ} \mathrm{C}$. The kinetic data obtained from $0.01 \mathrm{M}$ EDTA was used to simulate desorption equations. The Sequential extraction method was also used as a suitable method for identification of chemical forms of $\mathrm{Ni}$ and its mobility. According to the results, application of amendments reduced exchangeable and carbonate forms of Nirate with respect to control treatment. Changes in chemical forms of $\mathrm{Ni}$ and their conversion into less soluble forms in treated soils was observed with incubation time. Application of $\mathrm{Mn}^{0}, \mathrm{Fe}^{0}, \mathrm{CFA}$, and $\mathrm{B} 300$ to soil samples significantly decreased Ni desorption rate compared to the control treatment. The lowest Ni release was achieved by $\mathrm{Mn}^{0}$-treatment at $5 \%$. Biphasic pattern of $\mathrm{Ni}$ desorption kinetic was fitted well by the model of two first-order reactions. From the practical point of view, $\mathrm{Fe}^{0}, \mathrm{Mn}^{0}, \mathrm{CFA}$, and $\mathrm{B} 300$ treatmentsare effective in Ni stabilization, whileusing $\mathrm{Mn}^{0}$ and $\mathrm{Fe}^{0}$ at $5 \%$ can be recommended for immobilization of $\mathrm{Ni}$ from calcareous polluted soil.
\end{abstract}

Keywords: Nickel, amendments, stabilization, chemical forms, desorption kinetic

\section{Introduction}

Soil contamination by heavy metals, specially due to industrial development (Ramachandran and derived from anthropogenic sources, due to their toxicity effect on human health, has been known as a serious environmental problem for last few decades. Nickel (Ni) is one of the heavy metals, which its concentration significantly increases nowadays D'Souza, 2013). In addition, some sewage sludges and phosphate fertilizers may be important sources of $\mathrm{Ni}$ in agricultural soils (Kabata-Pendias and Mukherjee, 2007). Clay content, Fe and Mn-Oxides, and $\mathrm{pH}$ are the most important factors affecting the mobility of $\mathrm{Ni}$ in soils. Leaching down of Ni to the 
groundwater often occur in acidic condition with maximum ionic $\mathrm{Ni}(\mathrm{H} 2 \mathrm{O})_{6}{ }^{2+}$ concentration, however at alkaline condition, $\mathrm{Ni}$ may precipitate as hydroxides such as $\mathrm{Ni}(\mathrm{OH})_{3}$ or $\mathrm{Ni}_{4}(\mathrm{OH})_{4}{ }^{4+}$, with low solubility (Alloway, 2013). Nickel in soils is slightly mobile and associated with residual fraction (KabataPendias and Mukherjee, 2007). The stabilization of heavy metals-contaminated soils using contaminantimmobilizing amendments is a remediation procedure practical to decrease element dynamic in soils (Zhao et al., 2014). Stabilization of pollutants in soil can be achieved by adsorbing, complexing or precipitating of heavy metals. Heavy metals mobility is controlled by sorption and desorption characteristics of soil (Zhao et al., 2014). The desorption rate constants of heavy metals in soils can be related to its mobility and toxicity (Violante et al., 2008). In addition, the study of desorption kinetics can predict how the pollutants are transferred from the solid phase to the liquid phase (Jalali and Sajaditabar, 2013). Sequential extraction methods are applied to give qualitative and quantitative information about chemical forms of metals in soils (Jalali and Rostaei, 2011). However, fractionation of heavy metals by selective sequential extractions is practical, but previous studies showed that chemical extractants used in sequential extractions methods are not completely selective and specific (Saffari et al., 2009), and readsorption and redistribution of metal ions after release can occur (Saffari et al., 2009). In last decade, researchers have preferred to apply kinetic methodologies rather than the conventional sequential extraction techniques for evaluation of heavy metals behavior. Santos et al., (2010) explained that dynamic of heavy metals depends not only on their distribution among several species, but also on the dynamic properties of those species, such as chemical rate constants and diffusion coefficients. Hence, methodologies involving the kinetic fractionation of heavy metals in soils and sediments have been developed (Santos et al., 2010; Jalali and SajadiTabar, 2013). Bioavailability of heavy metals in soil is directly impactedby residence time (Jalali and khanlari, 2008). Heavy metals have highest bioavailability immediately after application to soil and with increasing time, bioavailability of metals decreases (jalali and khanlari, 2008; ).There is noinformationon stabilization of $\mathrm{Ni}$ in calcareous soils. Therefore, the objective of presentstudywere to investigate the influence of some amendments (coal fly ash, municipal solid waste compost, two types of biochar of rice husk prepared at 300 and $600^{\circ} \mathrm{C}$, zero valent iron and zero valent manganese)and incubation times on release and chemical transformation of $\mathrm{Ni}$ in a Ni-spiked soil, and to compare the ability of these amendments to reduce the mobility of $\mathrm{Ni}$ in a contaminated soil via desorption kinetic and sequential extraction experiments.

\section{Materials and Methods}

\subsection{Soil sampling and analysis}

Soil sample was collected from the $0-30 \mathrm{~cm}$ depth of a calcareous soil (Fine, mixed, mesic, FluventicCalcixerepts) from agricultural fields located in College of Agriculture, Bajgah, Shiraz, Fars Province, Iran. Soils was air-dried and passed through a $2 \mathrm{~mm}$ sieve. Soil texture, $\mathrm{pH}$, electrical conductivity (ECe), percentage of calcium carbonate equivalent (CCE), cation exchange capacity (CEC), andorganic matter (OM) determined using standard methods (Sparks et al., 1996).Plant-available of heavy metals were extracted by DTPA and determined by atomic absorption spectrophotometer. Total contents of heavy metals were determined using $4 \mathrm{M} \mathrm{HNo}_{3}$. The related properties of soil are presented in Table 1. 
Table 1. Selected chemical and physical properties of studied soil.

\begin{tabular}{ccccc}
\hline Property & Value & & Property & Value \\
\cline { 5 - 6 } \cline { 4 - 5 } nH & 7.8 & & Soluble Fein DTPA $\left(\mathrm{mg} \mathrm{kg} \mathrm{k}^{-1}\right)$ & 4.1 \\
$\mathrm{CCE}(\%)$ & 39.5 & & Soluble Cuin DTPA $\left(\mathrm{mg} \mathrm{kg}^{-1}\right)$ & 0.92 \\
Sand $(\%)$ & 27 & & Soluble Mn in DTPA $\left(\mathrm{mg} \mathrm{kg}^{-1}\right)$ & 5.6 \\
Clay $(\%)$ & 35 & & Soluble Pb in DTPA $\left(\mathrm{mg} \mathrm{kg}^{-1}\right)$ & Trace \\
OM $(\%)$ & 1.4 & & Soluble Ni in DTPA $\left(\mathrm{mg} \mathrm{kg}^{-1}\right)$ & Trace \\
CEC $\left(\mathrm{Cmol}(+) \mathrm{kg}^{-1}\right)$ & 15.8 & & Total Ni $\left(\mathrm{mg} \mathrm{kg}^{-1}\right)$ & 51 \\
EC $\left(\mathrm{dS} \mathrm{m}^{-1}\right)$ & 0.65 & & Total Fe $\left(\mathrm{mg} \mathrm{kg}^{-1}\right)$ & 30554 \\
\hline
\end{tabular}

Table 2. Summary of the Sequential extraction procedure used in this study

\begin{tabular}{|c|c|c|c|c|}
\hline $\begin{array}{l}\text { g soil:mL } \\
\text { solution }\end{array}$ & Extracting solution & Shaking time (h) & $\begin{array}{l}\text { Chemical form of } \\
\mathrm{Ni}\end{array}$ & Symbol \\
\hline $10: 40$ & $1 \mathrm{M} \mathrm{Mg}\left(\mathrm{NO}_{3}\right)_{2}$ & 2 & Exchangeable & EX \\
\hline $10: 40$ & $1 \mathrm{M} \mathrm{NaOAc}\left(\mathrm{pH}=5 \mathrm{CH}_{3} \mathrm{COOH}\right)$ & 5 & Carbonate- bound & Car \\
\hline $10: 20$ & $0.7 \mathrm{M} \mathrm{NaOCl}(\mathrm{pH}=8.5)$ & 0.5 in boiling water bath & Organically- bound* & $\mathrm{Om}$ \\
\hline $5: 50$ & $0.1 \mathrm{M} \mathrm{NH}_{2} \mathrm{OH} . \mathrm{HCl}\left(\mathrm{pH}=2 \mathrm{HNO}_{3}\right)$ & 0.5 in boiling water bath & Mn-oxide- bound & $\mathrm{Mn}-\mathrm{OX}$ \\
\hline $5: 50$ & $0.25 \mathrm{M} \mathrm{NH}_{2} \mathrm{OH} . \mathrm{HCl}+0.25 \mathrm{M} \mathrm{HCl}$ & 0.5 at $50^{\circ} \mathrm{C}$ in water bath & Amorphous Fe-oxide-bound & $\mathrm{FeA}-\mathrm{Ox}$ \\
\hline $5: 50$ & $\begin{array}{c}0.2 \mathrm{M}(\mathrm{NH} 4)_{2} \mathrm{C}_{2} \mathrm{O}_{4}+0.2 \mathrm{M} \mathrm{H}_{2} \mathrm{C}_{2} \mathrm{O}_{4} \\
+0.1 \mathrm{MC}_{6} \mathrm{H}_{8} \mathrm{O}_{6}\end{array}$ & 0.5 in boiling water bath & Crystalline Fe- oxide-bound & $\mathrm{FeC}-\mathrm{Ox}$ \\
\hline
\end{tabular}

*Two times extraction

Table 3. Equations fitted to describe Ni release kinetic

\begin{tabular}{|c|c|c|}
\hline Model & Equation & Parameters \\
\hline Zero order & $\mathrm{q}_{\mathrm{t}}=\mathrm{q}_{0}-\mathrm{k}_{0} \mathrm{t}$ & $\mathrm{K}_{0}$, zero order rate constant $\left(\mathrm{mg} \mathrm{Ni} \mathrm{kg}^{-1} \mathrm{~h}^{-1}\right)$ \\
\hline First order & $\ln q_{t}=\ln q_{0}-k_{1} t$ & $\mathrm{k}_{\mathrm{l}}$, first-order rate constant $\left(\mathrm{h}^{-1}\right)$ \\
\hline Second order & $1 / \mathrm{q}_{\mathrm{t}}=1 / \mathrm{q}_{0}-\mathrm{k}_{2} \mathrm{t}$ & $\mathrm{k}_{2}$, second-order rate constant $\left[\left(\mathrm{mg} \mathrm{Ni} \mathrm{kg}^{-1}\right)^{-1}\right]$ \\
\hline Third order & $\mathrm{tl} / \mathrm{q}_{1}^{2}=1 / \mathrm{q}_{0}^{2}-\mathrm{k}_{3}$ & $\mathrm{k} 3$, third-order rate constant $\left[\left(\mathrm{mg} \mathrm{Ni} \mathrm{kg}^{-1}\right)^{-2} \mathrm{~h}^{-2}\right]$ \\
\hline Parabolic diffusion & $\mathrm{q}_{\mathrm{t}}=\mathrm{q}_{0}-\mathrm{k}_{\mathrm{p}} \mathrm{t}^{1 / 2}$ & $\mathrm{kp}$, diffusion rate constant $\left[\left(\mathrm{mg} \mathrm{Ni} \mathrm{g}^{-1}\right)^{-0.5}\right]$ \\
\hline Simple Elovich & $\mathrm{q}_{\mathrm{t}}=1 / \beta \ln \left(\alpha_{\mathrm{s}} \beta_{\mathrm{s}}\right)+\left(1 / \beta_{\mathrm{s}}\right) \ln \mathrm{t}$ & $\begin{array}{l}\alpha_{\mathrm{s}} \text {, initial desorption rate }\left(\mathrm{mg} \mathrm{Ni} \mathrm{kg}^{-1} \mathrm{~h}^{-1}\right) \text {, } \\
\beta_{\mathrm{s}} \text { desorption constant }\left[\left(\mathrm{mg} \mathrm{Ni} \mathrm{kg}^{-1}\right)^{-1}\right]\end{array}$ \\
\hline Two-constant rate & $\mathrm{q}_{\mathrm{t}}=\mathrm{at}^{\mathrm{b}}$ & $\begin{array}{l}\text { a, initial desorption rate constant }\left(\mathrm{mg} \mathrm{Ni} \mathrm{kg}^{-1} \mathrm{~h}^{-1}\right)^{\mathrm{b}} \\
\mathrm{b} \text {, desorption rate coefficient }\left[\left(\mathrm{mg} \mathrm{Ni} \mathrm{kg}^{-1}\right)^{-1}\right]\end{array}$ \\
\hline
\end{tabular}

$\mathrm{q}_{0}$ and $\mathrm{q}_{\mathrm{t}}$ are the amount of Ni desorption $\left(\mathrm{mg} \mathrm{kg}^{-1}\right)$ at time zero and $\mathrm{t}$, respectively. 
Table 4. Values of seven equations and a model in examined soils after 45 days of incubation time

\begin{tabular}{|c|c|c|c|c|c|c|c|c|c|c|c|c|c|c|}
\hline Equation & Value & S1 & S2 & S3 & S4 & S5 & S6 & S7 & S8 & S9 & S10 & S11 & S12 & Control \\
\hline Zero & $\mathbf{R}^{2}$ & 0.57 & 0.5 & 0.51 & 0.44 & 0.4 & 0.39 & 0.38 & 0.4 & 0.37 & 0.44 & 0.37 & 0.4 & 0.39 \\
\hline order & SE & 3.42 & 3.36 & 3.48 & 3.71 & 3.48 & 3.77 & 3.74 & 3.68 & 3.41 & 3.56 & 4.1 & 3.74 & 3.9 \\
\hline \multirow{2}{*}{$\begin{array}{l}\text { First } \\
\text { order }\end{array}$} & $\mathbf{R}^{2}$ & 0.32 & 0.29 & 0.29 & 0.24 & 0.23 & 0.23 & 0.22 & 0.23 & 0.21 & 0.23 & 0.21 & 0.22 & 0.23 \\
\hline & SE & 4.62 & 4.35 & 5.45 & 3.32 & 3.73 & 3.34 & 4.32 & 4.45 & 4.8 & 4.28 & 4.34 & 4.01 & 4.1 \\
\hline \multirow{2}{*}{$\begin{array}{c}\text { Second } \\
\text { order }\end{array}$} & $\mathbf{R}^{2}$ & 0.09 & 0.1 & 0.08 & 0.07 & 0.08 & 0.09 & 0.08 & 0.07 & 0.08 & 0.07 & 0.07 & 0.07 & 0.09 \\
\hline & SE & 7.66 & 6.99 & 7.87 & 7.92 & 7.63 & 7.8 & 7.62 & 7.54 & 7.63 & 7.65 & 7.91 & 7.82 & 7.26 \\
\hline \multirow{2}{*}{$\begin{array}{l}\text { Third } \\
\text { order }\end{array}$} & $\mathbf{R}^{2}$ & 0.03 & 0.03 & 0.03 & 0.03 & 0.03 & 0.03 & 0.03 & 0.03 & 0.03 & 0.03 & 0.03 & 0.03 & 0.04 \\
\hline & SE & 9.35 & 8.44 & 10.41 & 7.05 & 7.65 & 6.77 & 8.26 & 6.81 & 6.83 & 7.5 & 7.33 & 5.97 & 7.38 \\
\hline \multirow{2}{*}{$\begin{array}{l}\text { Parabolic } \\
\text { diffusion }\end{array}$} & $\mathbf{R}^{2}$ & 0.81 & 0.75 & 0.75 & 0.67 & 0.63 & 0.63 & 0.61 & 0.63 & 0.59 & 0.66 & 0.6 & 0.64 & 0.62 \\
\hline & SE & 2.38 & 2.37 & 2.85 & 2.07 & 2.42 & 2.16 & 2.72 & 2.13 & 2.21 & 2.19 & 2.37 & 1.83 & 2.37 \\
\hline \multirow{4}{*}{$\begin{array}{l}\text { Simple } \\
\text { Elovich }\end{array}$} & $\alpha s$ & 26.2 & 22.31 & 23.26 & 35.69 & 52.92 & 54.18 & 74.21 & 26.31 & 67.81 & 52.58 & 23.29 & 17.6 & 93.58 \\
\hline & $\beta s$ & 0.62 & 0.68 & 0.56 & 0.9 & 0.81 & 0.91 & 0.74 & 0.92 & 0.94 & 0.85 & 0.86 & 1.05 & 0.84 \\
\hline & $\mathbf{R}^{2}$ & 0.98 & 0.99 & 0.99 & 0.98 & 0.98 & 0.97 & 0.97 & 0.97 & 0.97 & 0.99 & 0.97 & 0.98 & 0.98 \\
\hline & SE & 0.61 & 0.51 & 0.52 & 0.57 & 0.54 & $0.5 \mathrm{I}$ & 0.67 & 0.59 & 0.59 & 0.43 & 0.64 & 0.48 & 0.56 \\
\hline \multirow{4}{*}{$\begin{array}{l}\text { Two- } \\
\text { constant } \\
\text { rate }\end{array}$} & a & 3.88 & 3.33 & 3.74 & 3.1 & 3.84 & 3.57 & 4.43 & 2.67 & 3.6 & 3.64 & 2.56 & 2.08 & 4.44 \\
\hline & b & 0.22 & 0.23 & 0.24 & 0.21 & 0.2 & 0.19 & 0.2 & 0.23 & 0.19 & 0.2 & 0.25 & 0.25 & 0.18 \\
\hline & $\mathbf{R}^{2}$ & 0.89 & 0.9 & 0.89 & 0.82 & 0.86 & 0.84 & 0.82 & 0.84 & 0.8 & 0.81 & 0.83 & 0.83 & 0.83 \\
\hline & SE & 1.52 & 1.8 & 2.3 & 1.7 & 1.93 & 1.68 & 2.24 & 1.95 & 1.84 & 1.8 & 2.38 & 1.8 & 1.76 \\
\hline \multirow{7}{*}{$\begin{array}{l}\text { two first- } \\
\text { order } \\
\text { reactions }\end{array}$} & $\mathbf{Q}_{1}$ & 8.975 & 7.964 & 9.528 & 5.62 & 6.872 & 6.282 & 7.288 & 5.489 & 5.423 & 5.840 & 5.511 & 4.67 & 8.96 \\
\hline & $\mathbf{K}_{1}$ & 0.006 & 0.009 & 0.008 & 0.018 & 0.026 & 0.028 & 0.028 & 0.022 & 0.028 & 0.016 & 0.021 & 0.016 & 0.016 \\
\hline & $\mathbf{Q}_{2}$ & 6.877 & 6.009 & 7.486 & 5.331 & 5.490 & 4.824 & 6.465 & 4.780 & 5.515 & 6.124 & 5.256 & 4.23 & 4.23 \\
\hline & $\mathbf{K}_{2}$ & 1.326 & 1.011 & 0.808 & 1.242 & 2.049 & 2.592 & 2.008 & 0.997 & 1.687 & 1.466 & 0.7196 & 0.805 & 0.80 \\
\hline & $\mathbf{R}^{2}$ & 0.98 & 0.97 & 0.98 & 0.97 & 0.98 & 0.98 & 0.98 & 0.97 & 0.98 & 0.98 & 0.98 & 0.98 & 0.98 \\
\hline & SE & 0.6 & 0.48 & 0.51 & 0.53 & 0.54 & 0.54 & 0.58 & 0.55 & 0.58 & 0.52 & 0.66 & 0.49 & 0.53 \\
\hline & $\mathbf{Q}_{1} / \mathbf{Q}_{2}$ & 1.143 & 1.325 & 1.273 & 1.056 & 1.25 & 1.302 & 1.127 & 1.148 & 0.983 & 0.954 & 1.049 & 1.104 & 2.11 \\
\hline
\end{tabular}

Table 5. Values of seven equations and a model in examined soils after 90 days of incubation time

\begin{tabular}{|c|c|c|c|c|c|c|c|c|c|c|c|c|c|c|}
\hline Equation & Value & S1 & S2 & S3 & S4 & S5 & S6 & S7 & S8 & S9 & S10 & S11 & S12 & Control \\
\hline Zero & $\mathbf{R}^{2}$ & 0.31 & 0.3 & 0.33 & 0.38 & 0.22 & 0.31 & 0.34 & 0.31 & 0.3 & 0.31 & 0.28 & 0.32 & 0.34 \\
\hline order & SE & 3.01 & 2.84 & 3.21 & 2.57 & 3.43 & 3.21 & 3.45 & 3.22 & 3.7 & 3.27 & 3.47 & 3.22 & 3.17 \\
\hline \multirow{2}{*}{$\begin{array}{l}\text { First } \\
\text { order }\end{array}$} & $\mathbf{R}^{2}$ & 0.14 & 0.15 & 0.16 & 0.16 & 0.11 & 0.14 & 0.16 & 0.16 & 0.14 & 0.15 & 0.14 & 0.16 & 0.17 \\
\hline & SE & 6.9 & 7.1 & 6.83 & 6.81 & 7.42 & 6.51 & 6.43 & 6.12 & 6.33 & 6.38 & 6.51 & 5.98 & 6.13 \\
\hline \multirow{2}{*}{$\begin{array}{c}\text { Second } \\
\text { order }\end{array}$} & $\mathbf{R}^{2}$ & 0.03 & 0.04 & 0.04 & 0.04 & 0.03 & 0.04 & 0.04 & 0.04 & 0.04 & 0.04 & 0.04 & 0.04 & 0.06 \\
\hline & SE & 7.44 & 7.1 & 7.22 & 7.432 & 7.74 & 7.1 & 7.22 & 7.41 & 7.74 & 7.34 & 7.54 & 7.62 & 7.43 \\
\hline \multirow{2}{*}{$\begin{array}{l}\text { Third } \\
\text { order }\end{array}$} & $\mathbf{R}^{2}$ & 0.02 & 0.02 & 0.02 & 0.02 & 0.02 & 0.02 & 0.02 & 0.02 & 0.02 & 0.02 & 0.02 & 0.02 & 0.03 \\
\hline & SE & 6.74 & 6.87 & 6.3 & 6.45 & 6.02 & 6.9 & 6.3 & 6.35 & 6.71 & 6.63 & 6.23 & 6.28 & 6.15 \\
\hline \multirow{3}{*}{$\begin{array}{l}\text { Parabolic } \\
\text { diffusion }\end{array}$} & $\mathbf{R}^{2}$ & 0.52 & 0.51 & 0.55 & 0.6 & 0.41 & 0.52 & 0.56 & 0.53 & 0.51 & 0.53 & 0.49 & 0.55 & 0.57 \\
\hline & SE & 2.28 & 2.37 & 2.85 & 2.07 & 2.48 & 2.31 & 2.08 & 2.13 & 2.21 & 2.19 & 2.37 & 1.83 & 2.37 \\
\hline & $\alpha s$ & 27.5 & 36.1 & 35.5 & 25.3 & 53.13 & 30.99 & 23.96 & 17.71 & 39.3 & 29.7 & 30.91 & 10.28 & 26.26 \\
\hline \multirow{3}{*}{$\begin{array}{l}\text { Simple } \\
\text { Elovich }\end{array}$} & $\beta s$ & 0.99 & 0.97 & 1.11 & 1.1 & 1.15 & 0.88 & 1.09 & 0.84 & 1.12 & 1.08 & 1.21 & 1.27 & 0.87 \\
\hline & $\mathbf{R}^{2}$ & 0.95 & 0.94 & 0.96 & 0.98 & 0.89 & 0.95 & 0.96 & 0.94 & 0.95 & 0.96 & 0.94 & 0.95 & 0.97 \\
\hline & SE & 0.7 & 0.76 & 0.53 & 0.39 & 0.95 & 0.74 & 0.73 & 0.68 & 0.87 & 0.63 & 0.71 & 0.69 & 0.51 \\
\hline \multirow{4}{*}{$\begin{array}{l}\text { Two- } \\
\text { constant } \\
\text { rate }\end{array}$} & a & 2.18 & 2.56 & 2.39 & 2.13 & 2.38 & 2.43 & 2.07 & 2 & 2.37 & 2.2 & 2.09 & 1.29 & 2.58 \\
\hline & b & 0.27 & 0.25 & 0.24 & 0.25 & 0.24 & 0.27 & 0.26 & 0.3 & 0.24 & 0.25 & 0.24 & 0.3 & 0.25 \\
\hline & $\mathbf{R}^{2}$ & 0.73 & 0.75 & 0.75 & 0.75 & 0.68 & 0.73 & 0.77 & 0.78 & 0.73 & 0.74 & 0.75 & 0.8 & 0.8 \\
\hline & SE & 1.52 & 1.8 & 2.31 & 1.97 & 2.22 & 1.62 & 1.57 & 1.82 & 1.9 & 1.87 & 1.58 & 1.8 & 1.76 \\
\hline \multirow{7}{*}{$\begin{array}{l}\text { two first- } \\
\text { order } \\
\text { reactions }\end{array}$} & $\mathbf{Q}_{1}$ & 3.73 & 3.84 & 3.6 & 3.96 & 3.15 & 4.05 & 3.48 & 3.57 & 3.2 & 3.59 & 3.58 & 3.28 & 5.92 \\
\hline & $\mathbf{K}_{1}$ & 0.01 & 0.02 & 0.01 & 0.01 & 0.04 & 0.01 & 0.01 & 0.01 & 0.01 & 0.01 & 0.02 & 0.02 & 0.74 \\
\hline & $\mathbf{Q}_{2}$ & 5.85 & 6.09 & 5.35 & 5.05 & 5.41 & 6.88 & 5.27 & 7.17 & 5.65 & 5.46 & 4.42 & 3.68 & 5.02 \\
\hline & $\mathbf{K}_{2}$ & 0.61 & 0.68 & 0.85 & 0.82 & 0.83 & 0.6 & 0.62 & 0.3 & 0.76 & 0.72 & 0.98 & 0.43 & 0.01 \\
\hline & $\begin{array}{l}\mathbf{K}_{2} \\
\mathbf{R}^{2}\end{array}$ & 0.99 & $\begin{array}{l}0.90 \\
0.99\end{array}$ & 0.99 & $\begin{array}{l}0.02 \\
0.99\end{array}$ & $\begin{array}{l}0.03 \\
0.99\end{array}$ & $\begin{array}{l}0.0 \\
0.99\end{array}$ & $\begin{array}{l}0.02 \\
0.99\end{array}$ & 0.98 & 0.99 & 0.99 & 0.99 & $\begin{array}{l}0.45 \\
0.99\end{array}$ & 0.99 \\
\hline & SE & 0.26 & 0.31 & 0.27 & 0.31 & 0.32 & 0.32 & 0.34 & 0.39 & 0.25 & 0.36 & 0.31 & 0.25 & 0.28 \\
\hline & $\mathbf{Q}_{1} / \mathbf{Q}_{2}$ & 0.637 & 0.63 & 0.673 & 0.784 & 0.583 & 0.589 & 0.661 & 0.499 & 0.567 & 0.657 & 0.808 & 0.892 & 1.18 \\
\hline
\end{tabular}


Table 6. Simple correlation coefficient (r) between parameters of two first-order reactions, Elovich equation and chemical forms of $\mathrm{Ni}$ in amended soils after 45 (Below the diagonal, white background) and 90 (Above the diagonal, gray background) days of incubation time.

\begin{tabular}{|c|c|c|c|c|c|c|c|c|c|c|c|c|c|}
\hline & $Q_{1}$ & $\mathrm{~K}_{1}$ & $Q_{2}$ & $\mathrm{~K}_{2}$ & as & $\beta s$ & EX & Car & $\mathrm{Om}$ & $\mathrm{Mn}-\mathrm{Ox}$ & FeA-Ox & $\mathrm{FeC}-\mathrm{Ox}$ & Res \\
\hline$Q_{1}$ & 1 & $0.913^{\prime \prime}$ & 0.016 & -0.664 & -0.17 & $-0.582^{\circ}$ & 0.48 & 0.421 & 0.023 & 0.105 & 0.104 & 0.305 & -0.413 \\
\hline$K_{1}$ & -0.507 & 1 & -0.164 & $-0.711^{\circ}$ & -0.078 & -0.396 & 0.371 & 0.483 & -0.021 & 0.102 & 0.212 & 0.38 & -0.463 \\
\hline$Q_{2}$ & 0.562 & -0.408 & 1 & -0.141 & 0.193 & $-0.802^{-\prime}$ & $0.607^{*}$ & $-0,406$ & $0.727^{\circ}$ & -0.499 & -0.169 & -0.301 & 0.499 \\
\hline $\mathrm{K}_{2}$ & -0.123 & $0.720^{-}$ & 0.056 & 1 & 0.527 & 0.601 & -0.286 & -0.043 & -0.393 & -0.164 & -0.205 & -0.255 & 0.309 \\
\hline as & 0.155 & $0.610^{\circ}$ & -0.208 & 0.441 & 1 & 0.082 & $0.404^{\prime \prime}$ & 0.213 & -0.046 & -0.466 & -0.107 & -0.226 & 0.246 \\
\hline$\beta s$ & $-0.871^{-}$ & 0.571 & $-0.857^{\prime \prime}$ & 0.087 & 0.13 & 1 & -0.741 & 0.115 & $-0.678^{\circ *}$ & 0.258 & 0.078 & 0.086 & -0.11 \\
\hline EX & $0.546^{\circ}$ & -0.054 & -0.12 & 0.171 & 0.403 & -0.302 & 1 & 0.263 & $0.611^{\circ}$ & -0.212 & -0.289 & -0.371 & -0.07 \\
\hline Car & 0.409 & -0.357 & -0.08 & -0.45 & -0.061 & -0.235 & 0.345 & 1 & -0.198 & 0.446 & $=0.311$ & 0.018 & $-0.809^{\prime}$ \\
\hline $\mathrm{Om}$ & 0.254 & -0.071 & 0.022 & 0.222 & -0.026 & -0.249 & $0.694^{\prime \prime}$ & -0.122 & 1 & -0.037 & -0.408 & -0.289 & 0.053 \\
\hline $\mathrm{Mn}-\mathrm{Ox}$ & -0.128 & -0.103 & -0.35 & -0.344 & -0.344 & 0.215 & -0.109 & 0.447 & -0.084 & 1 & $-0.564^{\circ}$ & 0.31 & $-0.854^{\prime \prime}$ \\
\hline FeA-Ox & -0.166 & -0.087 & -0.071 & -0.292 & 0.174 & 0.252 & -0.404 & -0.282 & $-0.589^{\circ}$ & -0.397 & 1 & -0.009 & 0.431 \\
\hline $\mathrm{FeC}-\mathrm{Ox}$ & -0.041 & -0.207 & 0.44 & 0.039 & -0.401 & -0.207 & -0.444 & -0.32 & -0.246 & -0.52 & 0.323 & 1 & -0.245 \\
\hline Res & -0.381 & 0.374 & 0.206 & 0.483 & 0.108 & 0.165 & -0.429 & $-0.951^{-}$ & -0.047 & $-0.619^{\circ}$ & 0.361 & 0.48 & 1 \\
\hline
\end{tabular}

\subsection{Additive samples and incubation experiment}

Six different amendments including coal fly ash (CFA), municipal solid waste compost (MSWC), rice husk biochars prepared at $300^{\circ} \mathrm{C}(\mathrm{B} 300)$ and $600^{\circ} \mathrm{C}(\mathrm{B} 600)$, zero valent iron $\left(\mathrm{Fe}^{0}\right)$ and zero valent manganese $\left(\mathrm{Mn}^{0}\right)$ were used in present study. CFA and MSWC were collected from Zarand coal washing factory and recycling and municipal solid waste compost factory of Kerman, Iran, respectively. CFA contained $46.47 \%$ of $\mathrm{SIO}_{2}, 27.32 \%$ of $\mathrm{Al}_{2} \mathrm{O}_{3}, 0.9 \%$ of $\mathrm{TiO}_{2}, 6.73 \%$ of $\mathrm{Fe}_{2} \mathrm{O}_{3}, 4.56 \%$ of $\mathrm{CaO}, 0.15 \%$ of $\mathrm{BaO}, 0.14 \%$ of $\mathrm{SrO}, 2.32 \%$ of $\mathrm{MgO}, 3.42 \%$ of $\mathrm{K}_{2} \mathrm{O}$, $0.82 \%$ of $\mathrm{Na}_{2} \mathrm{O}, 4.6 \%$ of $\mathrm{SO}_{3}, 4.6 \%$ of $\mathrm{P}_{2} \mathrm{O}_{5}$, and $0.82 \%$ of $\mathrm{Mn}_{3} \mathrm{O}_{4}$, and its $\mathrm{pH}$ value was 9.1.MSWC had $38 \%$ organic matter, and contained $19 \mathrm{mgkg}^{-1}$ of $\mathrm{Cu}$, $28 \mathrm{mgkg}^{-1}$ of $\mathrm{Zn}, 25 \mathrm{mgkg}^{-1}$ of Fe, $11 \mathrm{mgkg}^{-1} \mathrm{Mn}, 13.3$ $\mathrm{mgkg}^{-1} \mathrm{~Pb}, 0.28 \mathrm{mgkg}^{-1} \mathrm{Cd}$, and $1.2 \mathrm{mgkg}^{-1}$ of $\mathrm{Ni}$, and its $\mathrm{pH}$ and $\mathrm{EC}$ valueswere 7.4 and 19.36, respectively. Biochars were prepared at $300^{\circ} \mathrm{C}$ and $600^{\circ} \mathrm{C}$ from rice husk. Husk samples (covered with aluminum foil) were placed in a furnace for $4 \mathrm{~h}$ to produce biochars.
Zero valent iron grit $\left(\mathrm{Fe}^{0}, 99.5 \%\right)$ and zero valent manganese grit $\left(\mathrm{Mn}^{0}, 99.5 \%\right)$ were used in present study.The concentrations of carbon, hydrogen and nitrogen in biochars samples were determined with $\mathrm{CHN}$ analyzer. The elemental content of $\mathrm{C}, \mathrm{H}$, and $\mathrm{N}$ in B300 sample was $41.57,2.11$, and $1.52 \%$ respectively. Its $\mathrm{pH}$ and $\mathrm{EC}$ values was6.2 and 13.1, respectively. In contrast, the average elemental composition of B 600 was $48.99 \% \mathrm{C}, 1.55 \% \mathrm{H}$, and the percentage of $\mathrm{N}$ was trace. Its $\mathrm{pH}$ and $\mathrm{EC}$ valueswere 8.7 and 21.2, respectively. In addition, Fourier Transform Infrared Spectroscopy (PerkinElmer FT-IR: Spectrum RXI) was used for the recognition of the morphology and structure of the produced biochars (Figure 1).

For incubation study, soil samples were placed in plastic cups and $\mathrm{Ni}$ was added at rate of $250 \mu \mathrm{g} \mathrm{g}^{-1}$ asNi $\left(\mathrm{NO}_{3}\right)_{2}$. Selected amendments including CFA, MSWC, biochars of rice husk (B300 and B600), $\mathrm{Fe}^{0}$, and $\mathrm{Mn}^{0}$ were added to each soil sample separately, at two levels $(2$ and $5 \% \mathrm{~W} / \mathrm{W})$. The soil samples were incubated for 45 and 90 days at $25^{\circ} \mathrm{C}$. The moisture was kept at about field capacity (FC) by adding distilled 
water to a constant weight. After incubation times, samples were air-dried and used for Ni desorption and fractionation studies. The description of experimental treatments is as; S1and S2 (MSWCat 2 and5 \%), S3 and S4 (CFAat 2 and $5 \%$ ), S5 and S6 (B300 at2 and 5
$\%), \mathrm{S} 7$ and $\mathrm{S} 8$ (B600at 2 and $5 \%), \mathrm{S} 9$ and $\mathrm{S} 10\left(\mathrm{Fe}^{0}\right.$ at2 and $5 \%), \mathrm{S} 11$ and $\mathrm{S} 12\left(\mathrm{Mn}^{0}\right.$ at 2 and $\left.5 \%\right)$. A control treatment (Control) with no amendment addition was also prepared. Each treatment was carried out in triplicates.

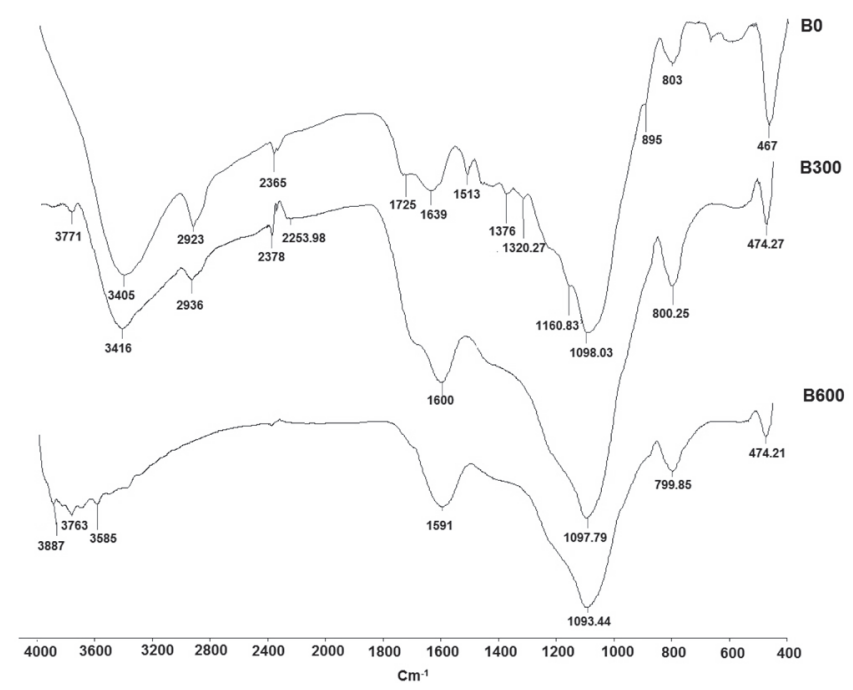

Figure1. FTIR spectra of rice husk before pyrolysis (B0), and after pyrolysis (B300 and B600).

\subsection{Sequential extraction procedures}

Chemical distribution of $\mathrm{Ni}$ in soil was determined using singh et al., (1988) method. The procedure was designed to separate $\mathrm{Ni}$ into seven fractions. Residual form (Res) is calculated by subtracting sum of six fractions from total Ni. Outline of the method is presented in Table 2. Also, the mobility of Ni was assessed by a "mobility factor" which calculated according to the equation: $(\mathrm{EX}+\mathrm{Car} / \mathrm{sum}$ of fractions) $\times 100$.

\subsection{Kinetics Studies}

For Ni desorption studies, $5 \mathrm{~g}$ of air-dried was placed in polyethylene tubes and extracted with $25 \mathrm{ml}$ of $0.01 \mathrm{M}$ EDTA at $\mathrm{pH}$ 7.0. Samples were shaken for periods of 0.08 to $2000 \mathrm{~h}(0.08,0.25,0.58,1.25,2.25,4.25,8.25,16.25$, $30.25,54.25,102.25,150,300,450,700,1000,1400$, and $2000 \mathrm{~h}$ ) at $25 \pm 2^{\circ} \mathrm{C}$ and then centrifuged immediately at $2500 \mathrm{rpm}$. The samples were filtered through Whatman 42 filter paper and Ni concentration was determined using atomic absorption spectrophotometer (Shimatzu AA-670G). Different kinetic equations were used to describe desorption of Ni in soils (Table 3). 

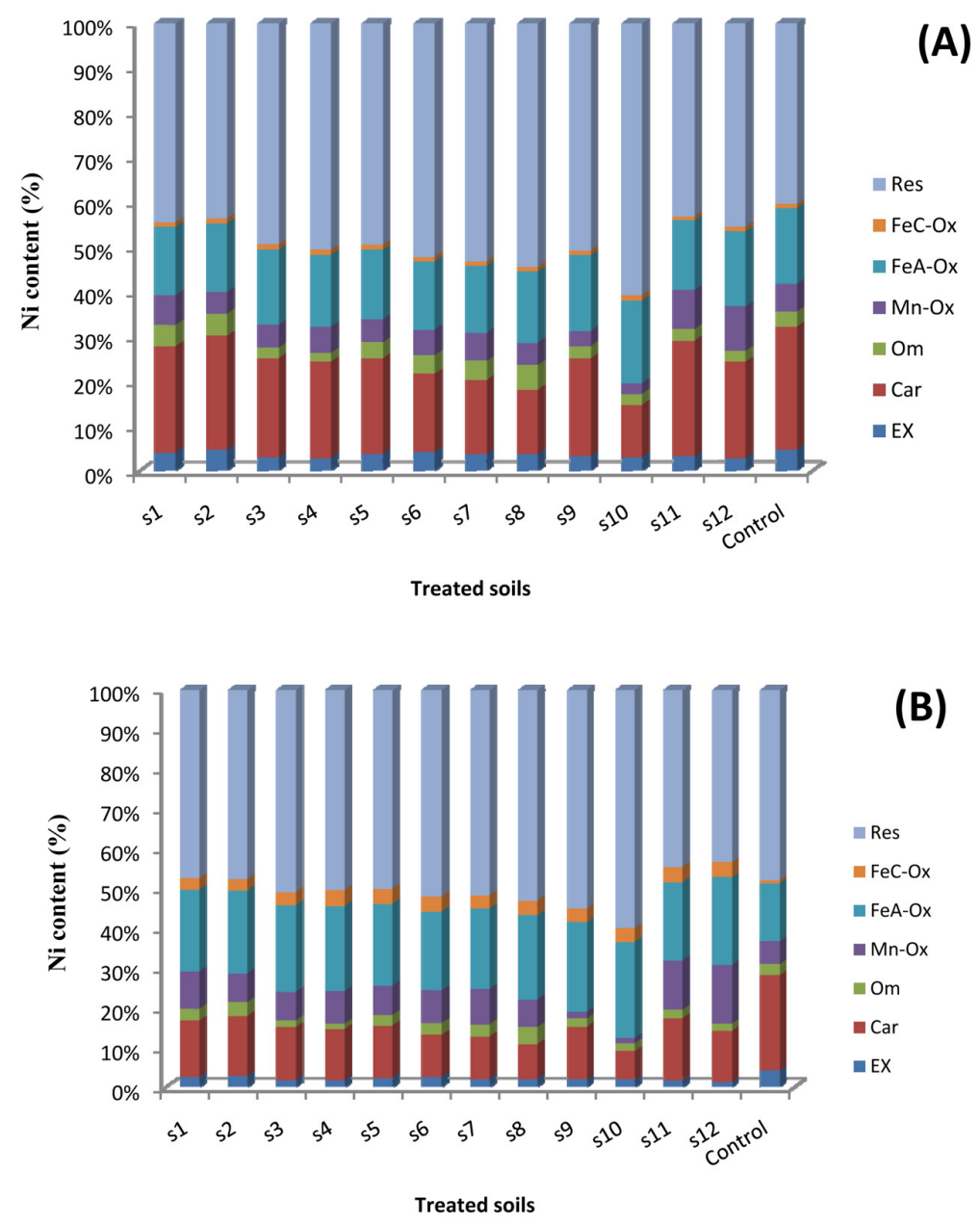

Figure 2. Relative distribution of chemical forms of $\mathrm{Ni}$ in amended soils after A) 45 andB) 90 days of incubation time.

\subsection{Model fitting to kinetic data}

A two first-order reaction model can divide heavy metal into three fractions (Santos et al., 2010; Jalali and Sajadi Tabar, 2013), $\mathrm{Q}_{1}, \mathrm{Q}_{2}$ and $\mathrm{Q}_{3}$, where:

$$
\begin{gathered}
q=Q_{1}\left(1-e^{-k 1 t}\right)+Q_{2}\left(1-e^{-k 2 t}\right) \\
Q_{3}=q_{\text {total }}-Q_{2}-Q_{1}
\end{gathered}
$$

q represents amount of metal released at time t. $\mathrm{Q}_{1}\left(\mathrm{mgkg}^{-1}\right)$ : "labile" fraction, readily extractable, associated to the rate constant $\mathrm{k}_{1}$.

$\mathrm{Q}_{2}$ ( $\mathrm{mg} \mathrm{kg} \mathrm{kg}^{-1}$ ): "moderately labile" fraction, less extractable, associated to the rate constant $\mathrm{k}_{2}$. $\mathrm{Q}_{3}\left(\mathrm{mg} \mathrm{kg}^{-1}\right)$ : Ni fraction, which is not extractable $\mathrm{q}_{\text {total: }}$ total concentration of $\mathrm{Ni}$ in soil. 
To determine the best-fitted model, a standard error of estimate was calculated for each equation and model. A relatively high values of coefficients of determination $\left(\mathrm{R}^{2}\right)$ and low values of standard errors of estimate (SE) were used as criteria for the selection of the best-fitted models. The standard error was calculated as follows:

$$
\mathrm{SE}=\left[\frac{\sum\left(E-E^{\prime}\right)^{2}}{n-2}\right]^{0.5}
$$

Where $\mathrm{E}$ and $\mathrm{E}^{\prime}$ are the measured and calculated amounts of Ni release in soil at time t, respectively, and $\mathrm{n}$ is the number of measurements.

\subsection{Statistical analysis}

The regression of linear, nonlinear procedure and other statistical analyses were calculated by Microsoft Excel 2010 and SPSS V19.

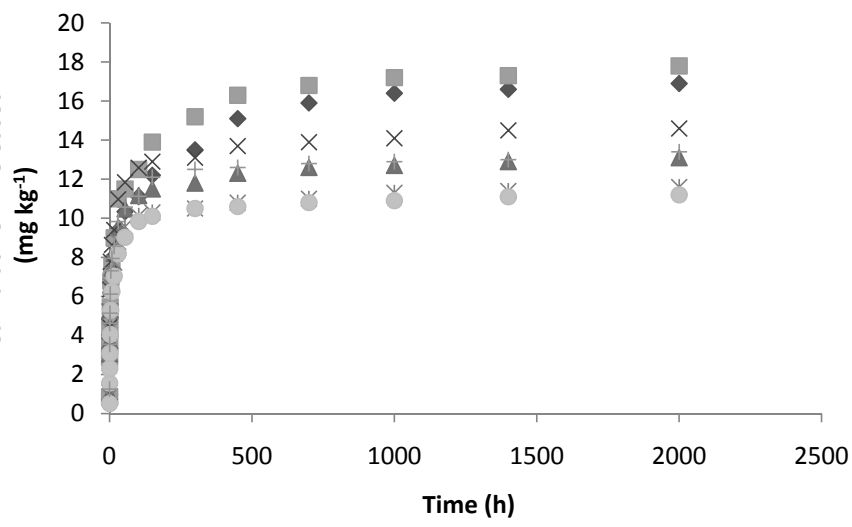

(a)

$$
\begin{aligned}
& \triangle \mathrm{MSWC} \\
& \square \mathrm{CFA} \\
& \triangle \mathrm{B} 300 \\
& \times \mathrm{B} 600 \\
& * \mathrm{Fe} 0 \\
& -\mathrm{MnO} \\
& + \text { control }
\end{aligned}
$$

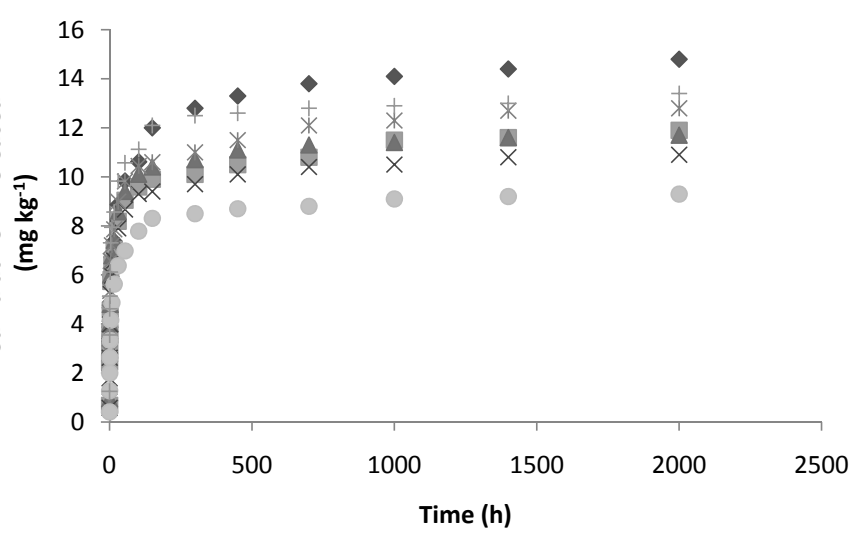

(b)

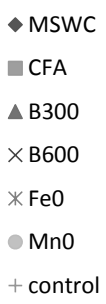

Figure 3ab. Cumulative released $\mathrm{Ni}$ with time in treated soils after 45 days of incubation time 


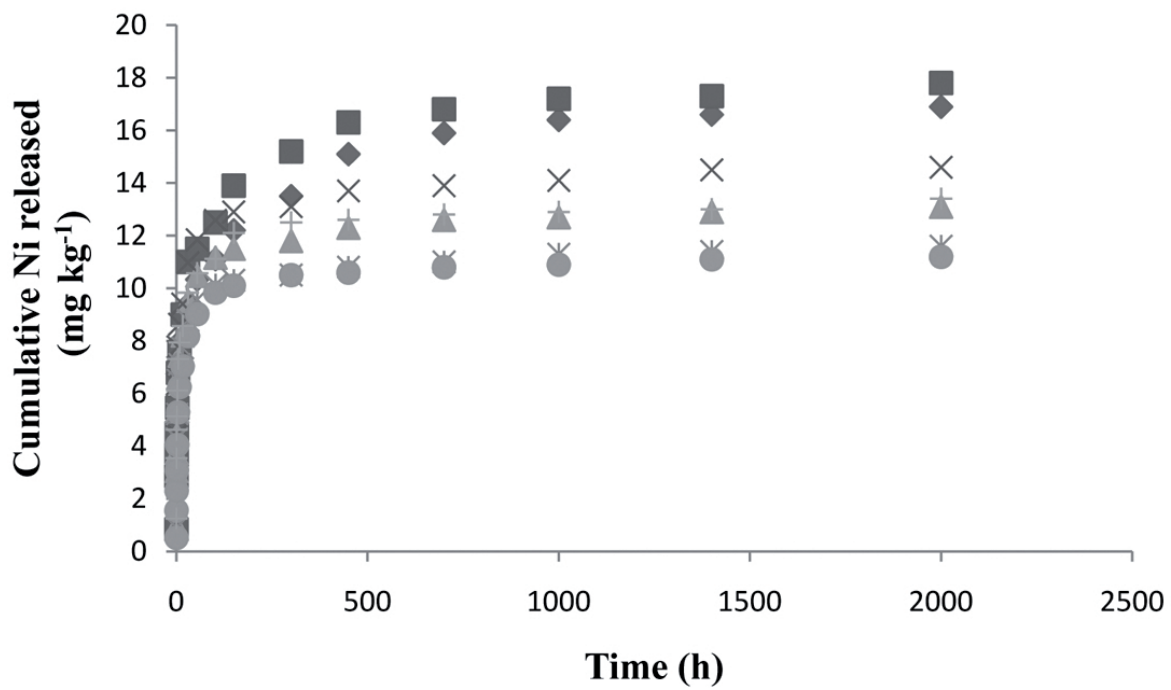

(a)

$\checkmark$ MSWC

CFA

$\triangle \mathrm{B} 300$

$\times B 600$

* Fe0

MnO

+ control

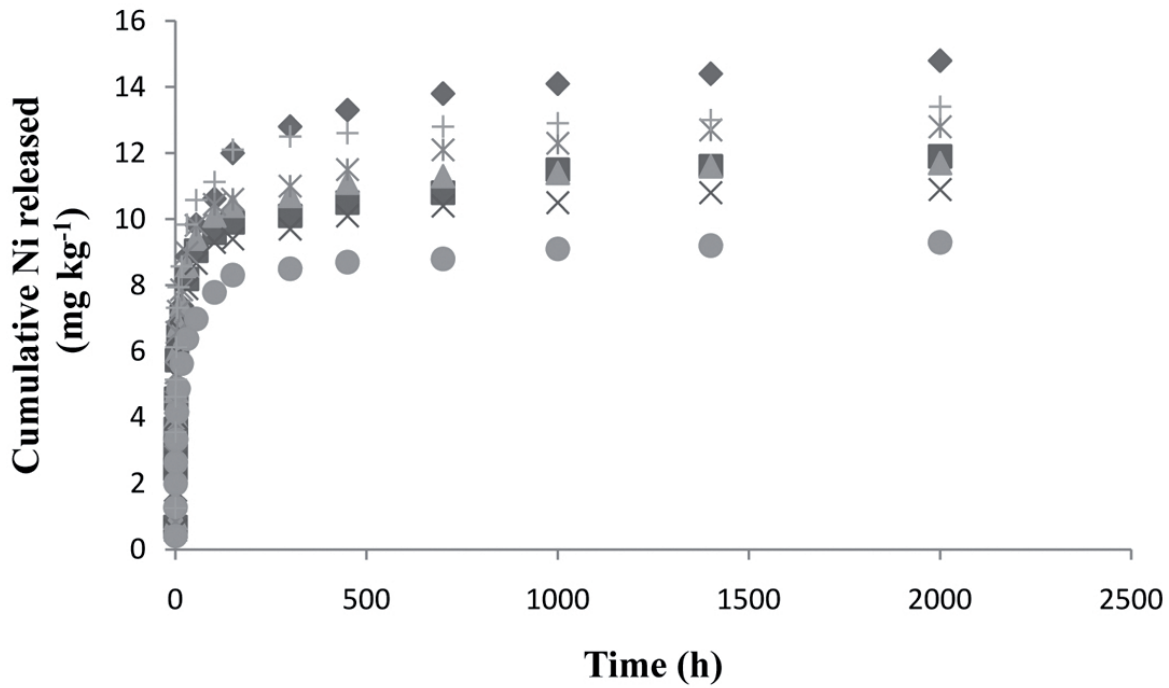

(b)

$\checkmark$ MSWC

CFA

$\triangle \mathrm{B} 300$

$\times \mathrm{B} 600$

$* \mathrm{FeO}$

MnO

+ control

Figure 3cd. Cumulative released $\mathrm{Ni}$ with time in treated soils after 90 days of incubation time 

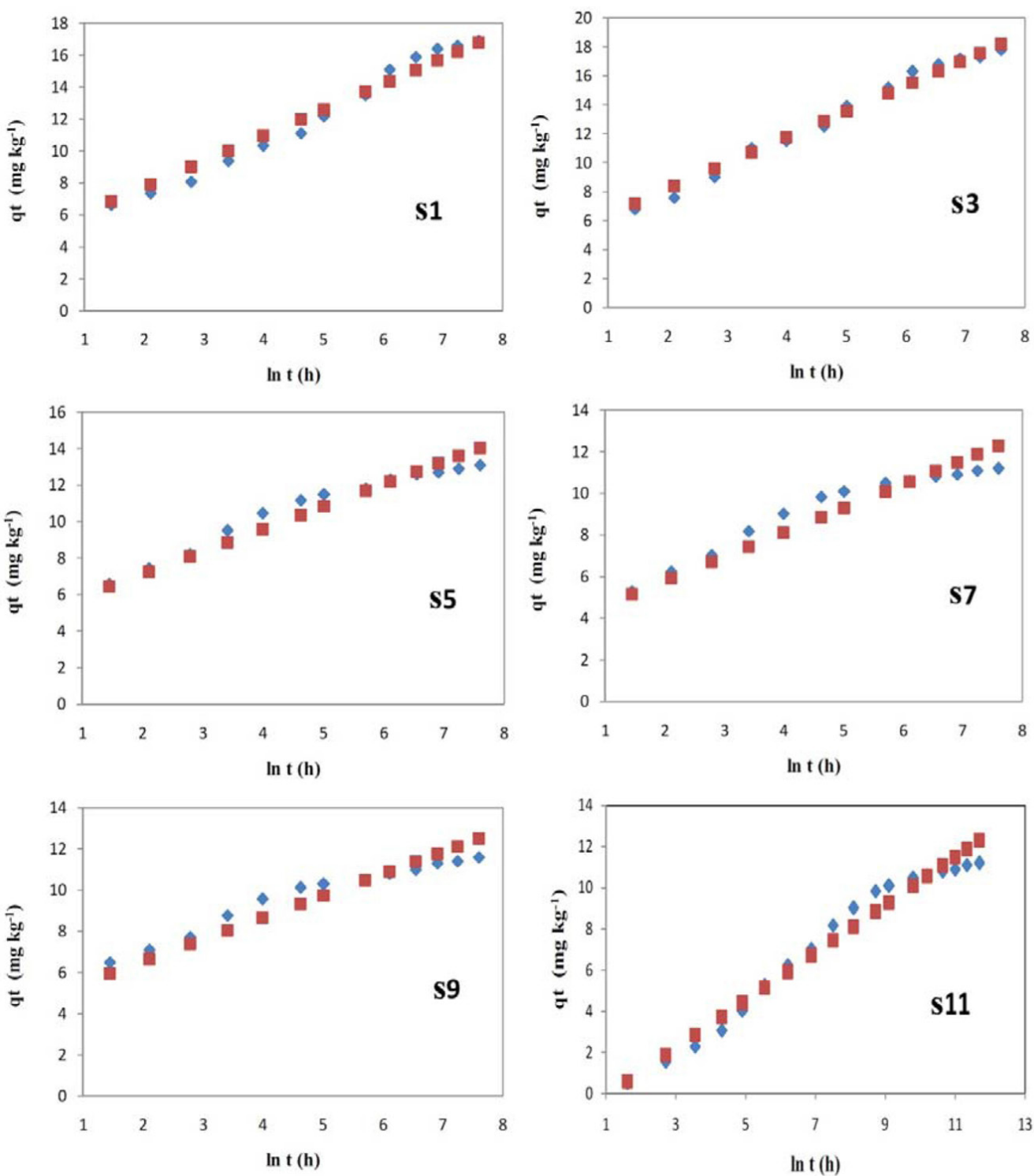

Fig. 4. Experimental ( $\bullet$ ) and predicted values ( $\bullet$ ) of Ni desorption in six amended soils after 45 days' incubationpredicted by simple Elovich equation. 

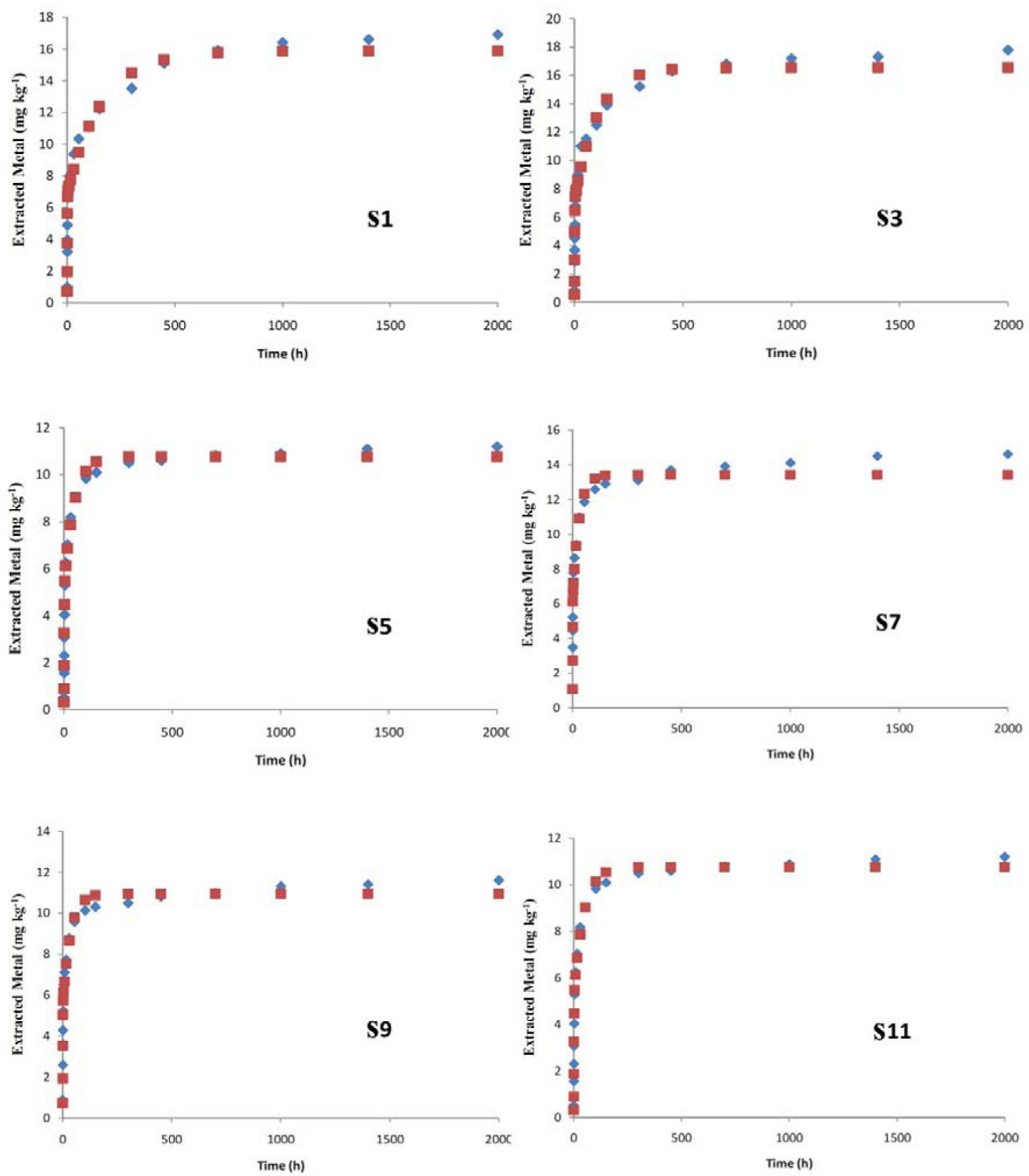

Fig. 5. Experimental $(\downarrow)$ and predicted values $(\boldsymbol{\square})$ of Ni desorption in six amended soils after 45 days' incubationpredicted by two first-order reaction model. 


\section{Result and Discussion}

\subsection{Characterization of Biochars amendments}

According to the results of biochars analysis, elimination of unstable compounds at the higher temperatures caused biochars to have higher percentages of carbon $(\mathrm{C})$, while much lower hydrogen $(\mathrm{H})$ and nitrogen $(\mathrm{N})$ contents. Increased pyrolysis temperature led to increased $\mathrm{pH}$ (from 6.2 to 8.7) and EC (from 13.1 to $21.2 \mathrm{dS} \mathrm{m}^{-1}$ ). Figure 1 showed the FTIR spectra of rice husk before pyrolysis (B0), and after pyrolysis (B300and B600). The sharp peak at 3405 and $3416 \mathrm{~cm}^{-1}$ in B0 and B300, and the weak peaks at around $3585 \mathrm{~cm}^{-1}$ in $\mathrm{B} 300$ and $\mathrm{B} 600$ are due to hydroxyl group $(-\mathrm{OH})$ stretching and functional group of phenol. The peaks at 2923 and $2936 \mathrm{~cm}^{-1}$ seen in B0 and B300 are ascribed to aliphatic $\mathrm{C}-\mathrm{H}$ deforming vibration and functional group of alkanes. These functional groups disappear at temperatures higher than $600^{\circ} \mathrm{C}$. The weak band at $1725 \mathrm{~cm}^{-1}$ for $\mathrm{B} 0$, which disappear at temperatures higher than $\mathrm{B} 300$, is assigned to $\mathrm{C}=\mathrm{O}$ stretching in carbonyl group and neutral functional group of aldehydes. The weak band at around $1640 \mathrm{~cm}^{-1}$ for $\mathrm{B} 0$ is due to the presence of or $\mathrm{C}=\mathrm{C}$ stretching (functional group of alkenes). The weak band $1539 \mathrm{~cm}^{-1}$ for $\mathrm{B} 0$ indicates the presence of N-O asymmetric stretch (nitro compounds). This band disappears at temperatures higher than 300C indicating the volatilization of nitrogen forms. The band at around $1600 \mathrm{~cm}^{-1}$ for $\mathrm{B} 300$ and B600 indicated the presence of aromatic $\mathrm{C}=\mathrm{O}$ ring stretching (likely $-\mathrm{COOH}$ ) or $\mathrm{C}=\mathrm{C}$ stretching of aromatic. This band is stronger in B600 compared to B300, which for this reason; $\mathrm{pH}$ was higher than $\mathrm{B} 300$. The weak bands at $1320 \mathrm{~cm}^{-1}$ and $1376 \mathrm{~cm}^{-1}$ in B0 indicate the presence of the $\mathrm{N}-\mathrm{O}$ asymmetric stretch (nitro compounds). This band disappears at temperatures higher than $300^{\circ} \mathrm{C}$, indicating the volatilization of nitrogen forms. The band at around $1090 \mathrm{~cm}^{-1}$ is due to aliphatic ether, alcohol $\mathrm{C}-\mathrm{O}$ or aromatic stretching in cellulose and hemicelluloses. Generally, the results from FTIR analysis of B600 showed the functional groups such as carboxylic bonds and aromatic $\mathrm{C}=\mathrm{O}$ ring stretching (likely - $\mathrm{COOH}$ ) was higher than $\mathrm{B} 300$, which increased its $\mathrm{pH}$.

\subsection{Chemical forms of $\mathrm{Ni}$ affected by aging and amendments}

Figures2A and 2B show the relative distributionof $\mathrm{Ni}$ in seven fractions in amended soil samples, incubated for 45 and 90 days, respectively. The results showedthat the distribution of chemical forms of Ni was affected by incubation times. Distribution of chemical forms of $\mathrm{Ni}$ in soil samples after 45 days'incubationfollowed the order: Res $>\mathrm{Car}>\mathrm{FeA}$ $\mathrm{OX}>\mathrm{Mn}-\mathrm{OX}>\mathrm{EX}>\mathrm{Om}>\mathrm{FeC}-\mathrm{OX}$. On the other hand, after 90 days' incubationNi fractions decreased in the following order: $\mathrm{Res}>\mathrm{FeA}-\mathrm{OX}>\mathrm{Car}>\mathrm{Mn}-\mathrm{OX}>\mathrm{FeC}-$ $\mathrm{OX}>\mathrm{Om}>\mathrm{EX}$. With increasing time $\mathrm{EX}, \mathrm{Car}$ and $\mathrm{Om}$ fractions decreased, but Mn-OX, FeA-OX, FeC-OX and Res fractions increased. Rajaie et al., (2008) reported that incubation time had a significant effect on chemical forms of Ni. Their results showed that, added soluble $\mathrm{Ni}$ at the beginning of experiment was presented in mobile fractions (EXand Car forms), but with increasing time EX and Car fractions converted into oxides and Res forms with lower mobility.Increasing $\mathrm{Ni}$ bound to FeA-OX after 90 days'incubation, could be due to high sorption affinity of Ni for Fe oxides (Rajaie et al., 2008). The change in chemical forms of heavy metals with time into less soluble forms reported by others (Jalali and Rostaei, 2011; Jalali and Khanlari, 2008).In soil samples, Ni was strongly bound with Res fraction, which was in agreement with otherstudies (Jalali and SajadiTabar, 2013; Rajaie et al.,2008). Significant reductions in 
EX form were observed in treated soil. The highest decrease in this fraction was observed following the application of $\mathrm{Mn}_{5 \%}^{0}$.EX form is an available fraction, which demonstrated application of amendments decreased Ni availability in soil samples. In addition, a considerable reduction of Car form following the soil treatment was observed.Nearly 57 and $70.26 \%$ of Car bound to Ni was decreased by $\mathrm{Fe}_{5 \%}^{0}$ in treated soil after 45 and 90 days' incubation compared to the control, respectively.Om fraction decreased after adding the $\mathrm{CFA}, \mathrm{Mn}^{0}$, and $\mathrm{Fe}^{0}$. In contrast,application of organic amendments (B300, B600 and MSWC) increased $\mathrm{Om}$ fraction. The highest decreasing and increasingamount of $\mathrm{Om}$ fraction followed by addition ofCFA ${ }_{5 \%}$ and $\mathrm{B} 600_{5 \%}$, respectively.GarciaDelgado et al., (2007) investigated the effect of sewage sludge on chemical forms of heavy metals. They showed that adding sewage sludge increased Cd concentration in EX and Om fractions, but did not affect of Ni fractionation.McGrath and Cegarra (1992) studied the impact of 20 years application ofsludge on chemical forms of Ni. They reported that after 10 years application of sludge, $\mathrm{Ni}$ in the $\mathrm{Car}, \mathrm{OM}$, and EX fractions increased, and the percentage of the Res fraction decreased with time. However, after 20 years application of sludge, EX, OM, and Car fractions declined slightly, and the Res fraction increased with time.The change in $\mathrm{Ni}$ bound to Mn-OX following the application of $\mathrm{Mn}^{0}$ and $\mathrm{Fe}^{0}$ was more evident. Application of $\mathrm{Mn}^{0}$ increased Mn-OX, but addition of $\mathrm{Fe}^{0}$ decreased Mn-OX fraction. Chemical forms of FeA-OX and FeC-Ox did not change in treated soils. In control soil, the mobility factor was $35.17 \%$ and $28.09 \%$ for 45 and 90 days'incubation, respectively. In soil samples, the lowest mobility factor was associated with $\mathrm{Fe}^{0}{ }_{5 \%}$. The mobility factors in S1-S12 respected to the controltreatment were $27.79,30.10$, $25.15,24.32,25.08,21.58,20.27,18.02,25.15$, $14.69,29.04$, and $24.29 \%$, respectively, in 45 days' incubation. In contrast, increasing incubation time from 45 to 90 days decreased mobility factor of Ni. The mobility factors in S1-S12compared tothe control were $16.68,17.87,15.05,14.54,15.43,13.11,12.68$, $10.77,15.17,8.98,17.27$, and $14.13 \%$, respectively in 90 days of incubation time. Addition of amendments generally led to a significant reduction in mobility of $\mathrm{Ni}$ in both of incubation times.

\subsection{Release of Ni affected by amendments}

Figure $3 \mathrm{ab}$ show the trend of Ni desorption in soil samples under different amendments and incubation times. The results showed that there was a similar pattern of initial rapid release followed by slower release of $\mathrm{Ni}$ with time, however the rate of $\mathrm{Ni}$ desorbed after 45 days' incubation was higher than 90 days' incubation. This could be due to the higher adsorption of Ni withtime. Depending on the metal and sorbent, residence time can affect the quantity of desorption of heavy metal (Jalali and Sajadi Tabar, 2013). Heavy metals have highest bioavailability immediately after application to soil (Jalali and Rostaei, 2011, Rajaie et al., 2008). Ainsworth et al., (1994) studied the effect of residence time on $\mathrm{Pb}^{2+}$ and $\mathrm{Co}^{2+}$ desorption from hydrous $\mathrm{Fe}$ oxide. They reported that residence time had significant effect on the amount of $\mathrm{Pb}$ and $\mathrm{Co}$ desorbed, which could be ascribed to the strong metal-soil complexes that occur and perhaps to diffusion processes. McNear et al., (2007) explained that, at high solution $\mathrm{Ni}$ concentrations and $\mathrm{pH}$ values $>6.8$, Ni-Al LDH precipitates (formation of $\mathrm{Ni}$ and Al layered double hydroxide) can lead to a reduction in Ni mobility with time. In comparison with the non-amended soil, $\mathrm{Mn}^{0}$ and $\mathrm{Fe}^{0}$ caused a reduction in Ni release, ranging from $4 \%$ to $30 \%$ for 45 days' incubation. The highest reduction in $\mathrm{Ni}$ release occurred following addition of $\mathrm{Mn}^{0}$ at $5 \%$. Moreover, compared to the control, addition of $\mathrm{Mn}^{0}$ or $\mathrm{Fe}^{0}$ 
significantly decreased Ni release by $17 \%$ to $36 \%$ for $\mathrm{Mn}_{5 \%}^{0}$ and $\mathrm{Fe}^{0}{ }_{5 \%}$, respectively for 90 days' incubation. $\mathrm{Ni}$ solution could be adsorbed to any of the surfaces soil solid phases, including layered silicates, $\mathrm{Fe}(\mathrm{Al})$ and Mn-OXides and organic substances (Arai, 2008). Fe and Mn-Oxides and hydroxides have an important role in retention, mobility and bioavailability of metals in contaminated soils (Kumpiene et al., 2008). Increasing iron oxides decreased heavy metals mobilization (Friesl et al., 2006, Kumpiene et al., 2008,). Kumpiene et al., (2006) applied 1\% $\mathrm{Fe}^{0}$ to reduce the mobility of $\mathrm{Cr}, \mathrm{Cu}, \mathrm{As}$ and $\mathrm{Zn}$ in a contaminated soil and showed that $\mathrm{As}$ and $\mathrm{Cr}$ concentrations decreased in soil leachates by $98 \%$ and 45\%, respectively. Friesl et al., (2003) showed that, application of red mud (as a soil amendment containing Fe oxides) decreased the mobility of $\mathrm{Zn}$, $\mathrm{Cd}$, and $\mathrm{Ni}$ in soils. By addition of MSWC at 2 and $5 \%$, the release of Ni significantly increased compared to the control soil in 45 days' incubation. It seems that, MSWC caused produce soluble complexes with $\mathrm{Ni}$ and increased Ni release in 45 days' incubation. In contrast, 90 days' incubation with MSWC at these rates led to a significant reduction of $\mathrm{Ni}$ release in a range of 7\%-10\% at 90 days' incubation. Arnesen and Singh (1999) reported that extractable $\mathrm{Cu}$ increased with increasing rate of peat, and suggested that lowering $\mathrm{pH}$ in peat-amended soil probably decreased the sorption of $\mathrm{Cu}$ in soils. Among the Ni desorption process, addition of CFA decreased $\mathrm{Ni}$ release compared to the control (Except for $\mathrm{CFA}_{2 \%}$ in 45 days' incubation). Addition of 2 and 5\% CFA decreased $\mathrm{Ni}$ release by $16 \%$ at the end of experiment. Application of CFA decreased efficiently mobility of soil heavy metals (Kumpiene et al., 2008). Reduction of heavy metal mobility by CFA is due to two mechanisms: Increasing $\mathrm{pH}$ and specific surface area, which causes the precipitation of insoluble phases and promoting metal sorption via surface complexation. Soil samples treated $\mathrm{B} 600$ at 2 and $5 \%$ decreased $\mathrm{Ni}$ release by $18 \%$ and $2.0 \%$ in of 90 days' incubation, respectively, but after 45 days' incubation, Ni desorption increased at $2 \%$. Addition of B300 at 2 and 5\% level decreased $\mathrm{Ni}$ release in both of incubation times (45 and 90 days). Application of B300 decreased Ni desorption by $2-20 \%$ in both incubation times. Depending on the temperature, biochars have different properties. Production of biochar at high temperature often produced biochar with highly aromatic substances, which recalcitrant to breakdown, high adsorptivity for heavy metals, high surface area, and high $\mathrm{pH}$ (Ladygina and Rineau, 2013). In contrast, biochars produced at low temperature often have high concentration of oxygenated functional groups, low $\mathrm{pH}$, and high radical content and able to chemisorb oxygen(Ladygina and Rineau, 2013). Biochars produced at low temperature, adsorption capacity of heavy metals is variable (depends on type of biochar and soil). The results from FTIR analysis of B600 showed the functional groups such as carboxylic bonds and aromatic $\mathrm{C}=\mathrm{O}$ ring stretching (likely $\mathrm{COOH}$ ) was higher than $\mathrm{B} 300$, which increased its $\mathrm{pH}$. It was expected that, biochars (especially produced at high temperature) could reduce Ni release considerable. Due To the fact that used soil in present study is calcareous, it seems that higher calcium carbonate content (41\%), probably was the main reason that biochar application could not efficiently affect immobilization of Ni. Among the amendments evaluated, application of $\mathrm{Mn}^{0}$ resulted in the highest reduction $\mathrm{Ni}$ desorption in both of incubation times.

\subsection{Equations and model fitting to kinetics of $\mathrm{Ni}$ desorption}

The trends in cumulative $\mathrm{Ni}$ release in soil sampleswere similar. Initial rate of $\mathrm{Ni}$ desorption was fast but declined until reached equilibrium 
(Figure 3cd). Desorption of $\mathrm{Ni}$ in all soil samples showed that $50 \%$ of total $\mathrm{Ni}$ desorbed within 16.25 h. Kirpichtchikova et al., (2006) concluded that initial fast release of heavy metals from soil can be related to water-soluble fraction and adsorption sites with lower bonding energy. On the other hand, slower desorption of metals depend on less mobile forms and to the dissolution of mineral constituents of soil (Polettini et al., 2007). Biphasic pattern of heavy metals desorption was observed by other (Sadegh et al., 2012; Jalali and Sajadi Tabar, 2013). The zero order, first order, second order, third order, parabolic diffusion, simple Elovich and Two-constant rate equations were used for describing Ni release kinetics up to $2000 \mathrm{~h}$ (Table 4 and 5). The zero order, first order, second order, and third order equations could not be described $\mathrm{Ni}$ desorption kinetic in soil samples. Desorption of $\mathrm{Ni}$ affected by many soil factors, hence, it was clear that release patterns of Ni could not be described by a simple rate equations. However,Ghasemifasaei et al., (2013) studied kinetics of $\mathrm{Ni}$ desorption from calcareous soils and reported that power function, first order, and second order equations were the best-fitted equations used to describe Ni desorption. Increasing order of reaction from zero to third caused the $\mathrm{R}^{2}$ decreased in soils studied, which reported by Sadegh et al. (2012). Amount of $\mathrm{R}^{2}$ and $\mathrm{SE}$ in the Tables 4 and 5 showed that best-fitted model for describing Ni release was simple Elovich equation. The Elovich equationis based on the assumptionthatthe activesurfaces of the sorbent are heterogeneous and therefore show different activation energies for chemisorption (Gupta and Babu, 2006). The higher fitness of the Elovich equation suggested that $\mathrm{Ni}$ sorption occur on heterogeneous surfaces of soil and the probably the mechanism is chemisorption. Witek-Krowiak et al., (2011) clarified that as value in Elovich equation is the rate of chemisorption at zero coverage and $\beta \mathrm{s}$ value is related to the extent of surface coverage and activation energy for adsorption.
Figure 4 shows the experimental extraction rate data and the fitted curves obtained with the simple Elovich equation for some amended soils. There was a good correlation between the fitted and experimental results for soil samples. Chien and Clayton (1980) concluded that the rate of $\mathrm{Cu}$ release increased when the value of asincreased or $\beta$ s decreased in simple Elovich equation. Application of amendments decreased the values of $\alpha$ s constant but the values of $\beta$ s constants increased compared to the controltreatment in 45 days' incubation. Nevertheless, the trend was not true for 90 days' incubation. Therefore, additions of amendments were effective in immobilizing $\mathrm{Ni}$ in 45 and not in 90 days' incubation. With increasing incubation time, $\alpha$ s and $\beta$ s did not changecompared to the control soil. Addition of amendments decreasedthe values of ' $a$ ' constant (in the two constant equation) more than control soil in 45 and 90 days' incubation. Kuo and Mikkelsen (1980) reported that increased in value of 'a' probably increased rate of zinc desorption from soils. This is in agreement with the assumptions made about the role of amendments in reductionNi desorption. The model of two first-order reactions were used by several researches (Santos et al., 2010; Jalali and SajadiTabar, 2013). This model could be used as a kinetic methodology for metal speciation in soils and sediments. The model of two first-order reaction exhibited biphasic reaction: rapidly extracted followed by slowly extracted of metal. Hence, it was expected that this model could best be described $\mathrm{Ni}$ desorption. This model approach indicates the quantity and the extraction rate of metal fractions (Santos et al., 2010). Tables 4 and 5 show that the parameters $\mathrm{Q}_{1}, \mathrm{~K}_{1}, \mathrm{Q}_{2}, \mathrm{~K}_{2}, \mathrm{R}^{2}, \mathrm{SE}$, and $\mathrm{Q}_{1} / \mathrm{Q}_{2}$. As results, $R^{2}$ was higher than 0.99 and values of $S E$ were lower than SE obtained from Elovich equation, so this model was better than Elovich equation to describe kinetics of $\mathrm{Ni}$ desorption in soil samples. Figure 5 shows representative curves calculated from two first- 
order reactions model. The results showed that, $\mathrm{K}_{1}$ (coefficients of $\mathrm{Ni}$ for the rapid release phase) were higher than $\mathrm{K}_{2}$ (coefficients of $\mathrm{Ni}$ for the slower release phase). The rate of $\mathrm{Q}_{1}$ (quickly extracted) in amended soils was lower than control soil, meaningreductionNi availability due to application amendments.High ratio of $\mathrm{Q}_{1} / \mathrm{Q}_{2}$ indicated that the labile metal fraction has greater than the less labile fraction. The lower ratio of $\mathrm{Q}_{1} / \mathrm{Q}_{2}$ of amended soils than control confirmed positive effect of amendment to stabilization of $\mathrm{Ni}$. Applicationamendments increasedthe rate of $\mathrm{Q}_{2}$ (slowly extracted) than control soil. This pattern was the same in both of incubation times. Brunori et al., (2005) noticed that $\mathrm{Q}_{1}$ could be related to EX fraction and part of Om fraction; $Q_{2}$ could be related to the Om residual and inorganic precipitates fraction, and $\mathrm{Q}_{3}$ could be related to residual fraction. Simple correlation coefficients (r) was estimated for relationships among parameters of the two first-order reactions model, constants of Elovich equation, and chemical forms of Ni (Table 6). There was a positive significant between $\mathrm{Q}_{1}$ with $\mathrm{EX}$ form, $\mathrm{K}_{1}$ with as, $\mathrm{K}_{1}$ with $\mathrm{K}_{2}, \mathrm{Om}$, and $\mathrm{EX}$ in 45 days incubation time. In contrast, a negative significant correlation was found between $Q_{1}$ with $\beta s, Q_{2}$ with $\beta$ s, Res with Car and Mn-OX fractions in 45 days incubation time. In 90 days' incubation time, there was a positive significant between $\mathrm{Q}_{1}$ with $\mathrm{K}_{1}, \mathrm{Q}_{2}$ with Om, EXwith as. On the other hand, a negative significant correlation was found between $\mathrm{Q}_{1}$ with $\mathrm{K}_{2}, \mathrm{Q}_{1}$ with $\beta \mathrm{s}, \mathrm{K}_{1}$ with $\mathrm{K}_{2}, \mathrm{Q}_{2}$ with $\beta \mathrm{s}$, $\beta \mathrm{s}$ with Om, and Res with Car and Mn-OX fractions in 90 days incubation time. Jalali and SajadiTabar (2013) reported that a significant correlation was found between $\mathrm{Q}_{2}$ from acid malic with Om, inorganic precipitates fraction, and Res fractions. The results of correlation coefficient between $\mathrm{Ni}$ fractions and parameters of two firstorder reactions and Elovich equation do not allow any general conclusion, because the data are much different from the Brunori et al., (2005) hypothesis.

\section{Conclusions}

In this study, the addition of coal fly ash, rice husk biochars prepared at $300^{\circ} \mathrm{C}$ and $600^{\circ} \mathrm{C}$, municipal solid waste compost, zero valent iron and zero valent manganese have been evaluated for use in Ni-spiked soil. The addition of amendments to contaminated soil induced changes in Nifractionation and desorption accordingly to the amendments properties. Zero valent iron and zero valent manganese decreased $\mathrm{Ni}$ desorption in soil, due to adsorption of $\mathrm{Ni}$ on surface of these amendments, which provides large surface area. Addition of coal fly ash changed the mobile fraction of Ni to less mobile in soils, which increased $\mathrm{Ni}$ stabilization, by increasing soil $\mathrm{pH}$. Biochar prepared at $600{ }^{\circ} \mathrm{C}$ was an ineffective amendment for immobilizing $\mathrm{Ni}$. It seems that high amount of calcium carbonate in studied soil probably was the main reason that biochar prepared at $600{ }^{\circ} \mathrm{C}$ could not efficiently affect immobilization of Ni. However, application of biochar prepared at $300{ }^{\circ} \mathrm{C}$ in soils significantly decreased $\mathrm{Ni}$ desorption rate, due to the increasing specific surface area that promoting Ni sorption through surface complexation. Different results obtained from application of municipal solid waste compost on $\mathrm{Ni}$ desorption did not allow any conclusion about positive effect of this amendment. In general, present study showed that from the practical point of view, all amendments (except for biochar prepared at $600^{\circ} \mathrm{C}$ and municipal solid waste compost) were effective in $\mathrm{Ni}$ immobilization, however application of zerovalent iron and zero valent manganese at $5 \%$ rate $(\mathrm{W} / \mathrm{W})$ were the best treatments to Ni immobilization. Further work is required to evaluate synergetic effects of selected amendments 
on $\mathrm{Ni}$ stabilization, and it seems necessary to assess the relationship between $\mathrm{Ni}$ fractions as affected by selected amendment and plant uptake in calcareous contaminated soils.

\section{Acknowledgement}

The authors appreciate Shiraz University for providing research facilities.

\section{References}

Ainsworth, C.C., Gassman, P. L., Pilon, J.L., Van Der Sluys, W.G. 1994. Cobalt, cadmium, and lead sorption to hydrous iron oxide, Residence time effect. Soil Sci. Soc. Am. J. 58, 1615-1623.

Alloway, B. 2013. Heavy metals and metalloids as micronutrients for plants and animals. In, Alloway BJ (ed) Heavy metals in soils. Springer, The Netherlands, pp 195-209.

Arai, Y . 2008. Spectroscopic evidence for Ni (II) surface speciation at the iron oxyhydroxideswater interface. Environ. Sci. Technol. 42, 11511156.

Arnesen, A.K.M., Singh, B.R. 1999. Plant uptake and DTPA-extractability of $\mathrm{Cd}, \mathrm{Cu}, \mathrm{Ni}$ and $\mathrm{Zn}$ in a Norwegian alum shale soil as affected by previous addition of dairy and pig manures and peat. Can. J. Soil Sci. 78, 531-539.

Chien, S.H., Clayton, W.R . 1980. Application of Elovich equation to the kinetics of phosphate release and sorption in soils. Soil Sci. Soc. Am. J. 44, 265-268.

Friesl, W., Lombi, E., Horak, O., Wenzel, W. 2003. Immobilization of heavy metals in soils using inorganic amendments in a greenhouse study. J. Plant Nutr. Soil Sci. 166, 191-196.
Garcia-Delgado, M., Rodriguez-Cruz, M.S., Lorenzo, L.F., Arienzo, M., Sanchez-Martin, M.J. 2007. Seasonal and time variability of heavy metal content and of its chemical forms in sewage sludges from different wastewater treatment plants. Sci. Total Environ. 382, 82-92.

Ghasemi-Fasaei, R., Mayel, S., Jarah, M. 2006. Investigation of Nickel Retention Kinetics of Selected Calcareous Soils of Southern Iran. Intl J. Agri. Crop Sci. 5 (17), 1890-1894.

Gupta, S., Babu, B. V.2006. Adsorption of chromium (VI) by a low cost adsorbent prepared from Tamarind Seeds. Chemcon-2006, Dec 27-30, India

Jalali, M., Khanlari, Z.V. 2008. Efect of aging process on the fractionation of heavy metals in some calcareous soils of Iran. Geoderma. 143, 26-40.

Jalali, M., Rostaei, L. 2011. Cadmium distribution in plant residues amended calcareous soils as a function of incubation time. Arch. Agron. Soil Sci. 57, 137-148.

Jalali, M., SajadiTabar, S. 2013. Kinetics extractions of nickel and lead from some contaminated calcareous soils. Soil Sediment Contam. 22, 5671.

Kabata-Pendias, A., Mukherjee, A.2007.Trace elements from soil to human. Springer-Verlag.

Kirpichtchikova, A.T., Manceau, A., Spadini, L., Panfili, F., Marcus, M.A., Jacquet, T. 2006. Speciation and solubility of heavy metals in contaminated soil using X-ray micro fluorescence, EXAFS spectroscopy, chemical extraction and thermodynamic modeling. Geochim. Cosmochim. Acta. 70, 2163-2190.

Kumpiene, J., Lagerkvist, A., Maurice, C. 2008. Stabilization of $\mathrm{As}, \mathrm{Cr}, \mathrm{Cu}, \mathrm{Pb}$ and $\mathrm{Zn}$ in soil using amendments-A review. Waste Manage. 28, 215-225. 
Kumpiene, J., Ore, S., Renella, G., Mench, M., Lagerkvist, A., Maurice, C. 2006. Assessment of zero-valent iron for stabilization of chromium, copper and arsenic in soil. Environ. Pollut. 144, 62-69.

Kuo, S., Mikkelsen, D. S.1980. Kinetics of zinc desorption from soils. Plant Soil. 56, 355-364.

Mcgrath, S. P., Cegarra, J. 1992. Chemical extractability of heavy metals during and after long-term applications of sludge to soil. J. Soil Sci. 43, 313-321.

McNear, D.H., Chaney, R.L., Sparks, D.L. 2007. The effects of soil type and chemical treatment on nickel speciation in refinery enriched soils, A multi-technique investigation. Geochim. Cosmochim. Acta. 71(9), 2190-2208.

Polettini, A., Pomi, R., Rolle, E. 2007. The effect of operating variables on chelant-assisted remediation of contaminated dredged sediment. Chemosphere. 66, 866-877.

Rajaie, M., Karimian, N., Yasrebi, J. 2008. Nickel transformation in two calcareous soil textural classes as affected by applied nickel sulfate. Geoderma. 144, 344-351.

Ramachandran, V., D’Souza, S. F. 2013.Adsorption of nickel by Indian soils. J. Soil Sci. Plant Nutr. 13(1), 165-173.

Sadegh, L., Fekri, M., Gorgin, N. 2012. Effects of poultry manure and pistachio compost on the kinetics of copper desorption from two calcareous soils. Arabian J. Geosci. 5, 571-578.
Saffari, M., Yasrebi, J., Karimian, N.A., Shan, X.Q. 2009.Effect of Calcium Carbonate Removal on the Chemical Forms of Zinc in Calcareous Soils by Three Sequential Extraction Methods. Res. J. Biol Sci. 4, 858-865.

Santos, S., Costa, C.A.E., Duarte, A.C., Scherer, H.W., Schneider, R.J, Esteves, V.I., Santos, B. H. 2010. Influence of different organic amendments on the potential availability of metals from soil: a study on metal fractionation and extraction kinetics by EDTA. Chemosphere. 78, 389-396.

Singh, J.P., Karwasra, S.P.S., Singh, M. 1988. Distribution and forms of copper, iron, manganese, and zinc in calcareous soils of India. Soil Sci. 146, 359-366.

Sparks, D. 1996. Methods of Soil Analysis, Part 3. Chemical Methods, Soil Science Society of America Inc., Madison, Wisc, USA.

Violante, A., Krishnamurti, G.S.R, Pigna, M. 2008. Factors affecting the sorption-sesorption of trace Elements in Soil Environments. In: Violante A., Huang P.M., Gadd G.M., (eds.), BiophysicoChemical Processes of Heavy Metals and Metalloids in Soil Environments, Wiley, New York, 169-213.

Witek-Krowiak, A., Szafran, R.G., Modelski, S. 2011. Biosorption of heavy metals from aqueous solutions onto peanut shell as a low-cost biosorbent, Desalin. 265, 126-134.

Zhao, Z., Jiang, G., Mao, R. 2014. Effects of particle sizes of rock phosphate on immobilizing heavy metals in lead zinc mine soils. J Soil Sci Plant Nutr. 14(2):258-266. 